Journal of Maternal and Child Health (2016), 1(4): 268-276

https://doi.org/10.26911/thejmch.2016.01.04.08

\title{
Mentoring of Pregnant Women at High Risk Program (Gerdaristi) to Reduce Maternal and Infant Mortality in Nganjuk, East Java
}

\author{
Titin Ratnaningsih'), Hermanu Joebagio²), Bhisma Murti'1) \\ 1) Masters Program in Public Health, Sebelas Maret University, Surakarta \\ 2) Faculty of Teaching and Educational Sciences, Sebelas Maret University
}

\begin{abstract}
Background: Maternal and infant mortality has the third rank in East Java. The effort to reduce the number of maternal and infant mortality is through Mentoring Program Pregnancy and High Risk Infants Mortality or Gerakan Pendampingan Ibu Hamil Beresiko Tinggi (Gerdaristi). This study aimed to investigate the success rate of implementation of Gerdaristi program in reducing Maternal Mortality Rate (MMR) and Infant Mortality Rate (IMR) in Nganjuk.

Subjects and Method: This was a case study with qualitative method. This was conducted in Nganjuk, East Java. A sample of 10 pregnant women, 4 cadres, 2 coordinator midwives, 2 community leaders, 1 of the IBI informant, 2 key informant from department of health were selected by using purposive sampling. The data collection used interview, Focus Group Discussion (FGD), observation and documentation. The data were analyzed by chain of evidence, triangulation, member check, checks the extension of participation and colleagues.

Results: Implementation Gerdaristi program every month hosted in the health center. Cadres assisted health centers and conducted home visits every week. Gerdaristi program success is as high as the number of maternal and infant mortality from year to year decline. Nevertheless they found several things including not maximal assistance from the volunteer and mother's level of knowledge about high-risk pregnancies are still lacking, and still have a maternal and infant mortality in some districts. This is due to several factors that inhibit awareness among pregnant women to give birth at the hospital as well as their lower mortality factor that cannot be predicted from the beginning.

Conclusion: Gerdaristi program has been implemented in accordance with the initial plan involving several related sectors, although there is a few things that implementation is not optimal, but rated this program has been quite successful.
\end{abstract}

Keywords: gerdaristi program, maternal mortality rate, infant mortality rate

Correspondence:

Titin Ratnaningsih. Masters Program in Public Health, Sebelas Maret University, Surakarta.

\begin{tabular}{l}
\hline BACKGROUND \\
Maternal Mortality Rate (MMR) and Infant \\
Mortality Rate (IMR) in Indonesia is still \\
high when compared with countries in \\
Southeast Asia, where in 2012, maternal \\
mortality rate in Indonesia has increased \\
from 228 per 100, ooo lives birth in 2007 to \\
359 per 100,ooo lives birth in 2012 (IDHS, \\
2012). Millennium Development Goals \\
(MDG's) have designed the UN MDG's
\end{tabular}

agenda to continue to develop a conception in the context of the framework or the post2015 development agenda, called Sustainable Develop ment Goals (SDG's). SDG's concept is necessary as a new development framework that accommodates all the changes that occur post $2015 \mathrm{MDG}$ 's, so that the target for reducing the MMR to 102 per 100,000 lives birth and IMR 23/1,000 (Bappenas, 2010). 
The maternal mortality rate in East Java province in the last five years a downward trend based maternal mortality Report (LKI) district/ cities in East Java. In 2012 to 2014 which reached reducing maternal mortality rate to $93.52 / 100,000$ $\mathrm{KH}$ by the number of maternal deaths reach 567 this case, the province of East Java has achieved the MDG's target of 2015 is 102/ $100,000 \mathrm{KH}$, but this figure is still the fifth highest contributor to death from all provinces in Indonesia. The case of the highest maternal mortality in East Java occurred in the area of Surabaya, Jember, Sidoarjo, Pasuruan, Malang, Jombang, Probolinggo, Gresik, Blitar, Banyuwangi, Sampang, Situbondo, Nganjuk, Bondowoso, Lumajang, Kediri and Tulungagung. IMR in East Java itself is said to have not reached the target $23 / 1$,ooo live birth by the number of infant deaths 5,229 babies.

Table 1. Number of maternal mortality and infant in Nganjuk

\begin{tabular}{ccc}
\hline Years & $\begin{array}{c}\text { Total of } \\
\text { Maternal } \\
\text { Mortality }\end{array}$ & $\begin{array}{c}\text { Total of Infant } \\
\text { Mortality }\end{array}$ \\
\hline 2010 & 17 & 212 \\
2011 & 22 & 258 \\
2012 & 25 & 314 \\
2013 & 24 & 327 \\
2014 & 17 & 172 \\
2015 & 12 & 170 \\
\hline
\end{tabular}

Based on the results of preliminary studies on January 10, 2016 at the District Health Office Nganjuk obtained the following data in Table 1.

In 2015, the number of maternal deaths in Nganjuk declined to 12 deaths. Of the 20 districts in Nganjuk there are 8 districts which are still there although maternal mortality has been running a program Gerdaristi.

Factors that contribute to maternal deaths can be broadly grouped into the cau- ses direct and indirect causes. The direct causes of maternal death are factors associated with complications of pregnancy, childbirth and postpartum like bleeding, pre-eclampsia/ eclampsia, infection, obstructed labor and abortion.

The indirect causes of maternal death are factors that aggravate the situation of pregnant women like four too (too young, too old, too often give birth, and too close spacing) according to the Demographic and Health Survey 2012 of $22.5 \%$, and that complicates the process of emergency response pregnancy, childbirth and postpartum. Another influential factor is the pregnant women who suffer from infectious diseases such as malaria, HIV/AIDS, tuberculosis, syphilis, non-communicable diseases such as hypertension, diabetes mellitus, heart disease, mental illness, or who are malnourished. See the above cases, the efforts to solve the problem of maternal mortality and infant in Nganjuk through Mentoring Program Maternal and Neonatal High Risk (GERDARISTI).

Gerdaristi is a mentoring program ANC high-risk pregnant women involving several sectors of the community empowerment efforts assisted by a cadre through appropriate technology is to use the Score card Poedji Rochjati. Program Evaluation Geraristi alone each year have been evaluated internally, but the evaluation was limited to the distribution of maternal deaths in each district.

The purpose of this study was to evaluate the mentoring program of pregnant women and high-risk neonates (Gerdaristi) to reduce MMR and IMR.

\section{SUBJECTS AND METHOD}

This was a case study with a qualitative method. Data collection was using interview (in depth interview) and Focus Group Discussion (FGD), observations and docu- 
Journal of Maternal and Child Health (2016), 1(4): 268-276

https://doi.org/10.26911/thejmch.2016.01.04.08

ment. This was conducted on evaluation contains basic Gerdaristi Program in Nganjuk. A sampling was a purposive sampling. Key informants in the Research has are midwives region, PKK and stakeholders at the district Nganjuk (Head of Health Family Office Nganjuk), whereas informant triangulation of pregnant women at high risk and families, cadres Posyandu, professional organizations (IBI), a character religious and community leaders. Data analysis used with all data from interviews, focus group discussions, observation and study of the document by performing data reduction in a summary and tabel to be easy to read and understand.

\section{RESULTS}

The study involved 10 pregnant women at high risk informants, four cadres assistant, two midwives coordinator, two community leaders, one person professional organizations (IBI), two key informants (Department of Health and the PKK). Age of informants vary ranging from 17 years to 54 years. The informants include pregnant women who have to follow the program Gerdaristi namely pregnant women entering high-risk category, Midwives Coordinator responsible for the implementation of activities Gerdaristi in each health center, volunteer mothers involved in assisting pregnant women at high risk, community leaders who know about the program Gerdaristi, professional organizations (IBI), which is a profession related to pregnancy, as well as policy makers PKK and Nganjuk District Health Office which is in charge of this activity Gerdaristi program

\section{Program Background}

Background gerdaristi program is the high MMR and IMR in Nganjuk, with the support of the Regent Nganjuk Nganjuk published Regent Decree No. 188/336/ K/
411.013/2013 and Regulation 52014 Nganjuk Regency.

\section{The program objectives}

Gerdaristi program objectives are to reduce MMR and IMR in Nganjuk. Another goal of which is to identify the identity of pregnant women, identify the socio-economic status, identify the status of environmental sanitation, mapping of high risk factors, improve knowledge, attitude and skills of cadres, analyzes the development of nutriational status, analyzes the development of health status, supporting the national program GSI.

\section{Target population}

The method of determining the target population through Screening KSPR Gerdaristi program that focuses on high-risk pregnant women. In addition determinant based on family socioeconomic status and nutritional status.

\section{Activity Program}

Gerdaristi program activities include examination of pregnant women at risk tow health center once a month, provide assistance in the home by a cadre of every single week, home visits by the PKK in the utilization of land and the provision of information about the home healthy and good environmental sanitation.

\section{Indicators of program success}

Table 2. Implementation program

\begin{tabular}{|c|c|}
\hline Planning & Implementation \\
\hline $\begin{array}{l}\text { 1. Assistance carried } \\
\text { out only in pregnant } \\
\text { women with high- } \\
\text { risk category }\end{array}$ & $\begin{array}{l}\text { 1. It has been } \\
\text { running for } \\
\text { almost } 3 \text { years do } \\
\text { mentoring for }\end{array}$ \\
\hline $\begin{array}{l}\text { 2. The classification } \\
\text { and not only KSPR } \\
\text { but the pre- } \\
\text { prosperous family } \\
\text { also }\end{array}$ & $\begin{array}{l}\text { high-risk pregnant } \\
\text { women } \\
\text { 2. It has been done } \\
\text { according to plan }\end{array}$ \\
\hline
\end{tabular}

Gerdaristi success indicators include the MMR and IMR down, great/rankings in 
East Java fell, the increase in the budget, an increase in resources, improve the system, to be accompanied by a willingness mother.

\section{Perceptions of informants know- ledge}

Knowledge informants were Head Kesga, TP PKK, Midwives, cadres, OP and TOMA and TOGA has good knowledge. It's just got some informants pregnant women do not understand the reasons why the program Gerdaristi.

\section{Attitude}

Entire related agencies are very supportive of this Gerdaristi program, evidenced by the participation of relevant agencies and local government by issuing Perbub Gerdaristi related programs and improving the quality of human resources for both PTT and civil servants midwives and pregnant women's own attitudes are very happy and grateful.

\section{Behavior}

Nganjuk and local government here is to provide budget funds entering the Nganjuk district budget increased every year for the achievement of the objectives of this program. The whole team Gerdaristi both midwife and cadres active in providing inspection and advisory services for highrisk pregnant women. Pregnant women active in participating in mentoring programs in the clinic each month. There are a few cadres who still do not provide guidance at home every week. Toma and toga actively disseminate to the entire community.

\section{Involvement}

All parties involved in the implementation of this gerdaristi gerdaristi them apart from the team itself is also of some of the relevant office.

\section{Motivation}

The equation in order to prevent maternal and infant mortality in the district Nganjuk Program resources

\section{Input}

There is no difference in both the quality of human resources, the human resources and infrastructure to support the program Gerdaristi in each health center.

Table 3. Skills program implementer

\begin{tabular}{ll}
\hline \multicolumn{1}{c}{ Skills } & $\begin{array}{c}\text { Officers were } \\
\text { running }\end{array}$ \\
\hline $\begin{array}{l}\text { The examination of preg- } \\
\text { nancy }\end{array}$ & Midwives \\
$\begin{array}{l}\text { Laboratory examination } \\
\text { Pregnancy counseling }\end{array}$ & $\begin{array}{l}\text { Laboratory staff } \\
\text { Midwives }\end{array}$ \\
$\begin{array}{l}\text { Hazard detection of preg- } \\
\text { nancy and child consulta- }\end{array}$ & SpOG dan SpA \\
tion & \\
$\begin{array}{l}\text { Mentoring at home } \\
\text { Health education about } \\
\text { healthy homes, sanitation } \\
\text { and land use empty }\end{array}$ & TP PKK \\
\hline
\end{tabular}

\section{Process}

There was no difference in the implementation of Gerdaristi program in each district.

\section{Results}

The number of maternal and infant mortality in each district is different. It is caused by factors that cannot be predicted from the beginning.

Table 4. Participation pregnant women and cadres

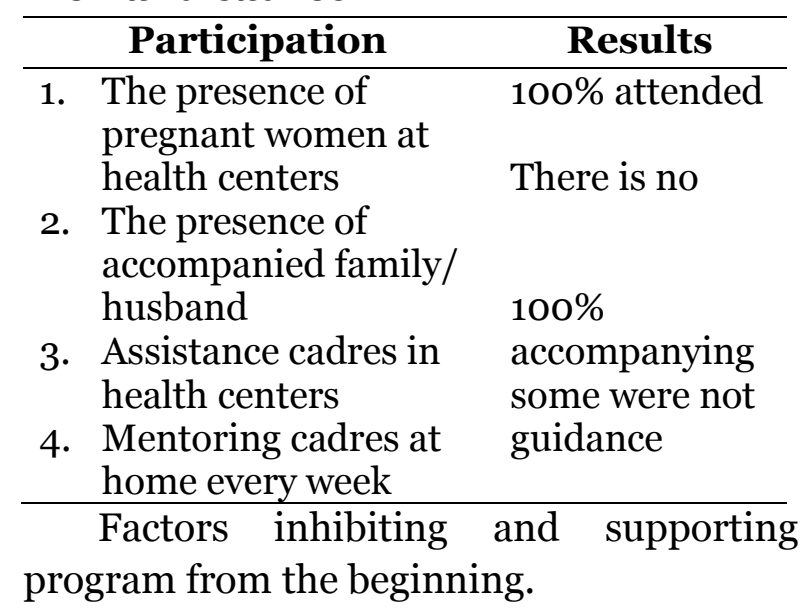

\section{Obstacle factor}

Factors inhibiting them is geography, awareness for antenatal care less, aware- 
Journal of Maternal and Child Health (2016), 1(4): 268-276

https://doi.org/10.26911/thejmch.2016.01.04.08

ness maternity hospital is low, health workers working below standard, high risk because of the age of many poor families, many, history of heart disease, participation midwife private clinic less, assuming that one of older family (grandmother), the number of Sp.OG and Sp.A less, emergency less space, not all midwives have the same standard.

\section{Supporting factors}

Factors supporting the program Gerdaristi them is hard work and a cadre of midwives, Local Government involvement in supplying the budget The involvement of relevant agencies and PKK.

\section{DISCUSSION}

\section{Background program}

Beginning of the Formation Program Gerdaristi Territory Nganjuk based on high MMR and IMR in Nganjuk in 2011, where the infant mortality rate topped No. 2 and MMR number 6 out of 38 cities/ regencies in East Java, based on the fact the real in the field finally the government in this regard Nganjuk Regents makes policies to suppress the MMR and IMR in Nganjuk by adopting the program's success Gentasibu (Movement Poverty Malnutrition), through the improvement of health services with guidance to pregnant women through childbirth.

This is according to research conducted by Irwan (2009), Agudelo (2005) and Feresu (2005) that the ability the implementation of a regional health was measured by determining the level MMR and IMR in 100,00o live births.

\section{Program Objectives}

That the purpose of the formation of Gerdaristi program is to reduce MMR and IMR in the district Nganjuk through the empowerment of families and communities as well as the efforts of assistance to pregnant women in the provision of information and health facilities that are expected to prevent the occurrence of MMR and IMR in Nganjuk. In addition to it that the objectives are Gerdaristi is, more specifically, is to identify the identity of pregnant women, identify the socio-economic status, identify the status of environmental sanitation as well, mapped the risk factors for pregnant women in Nganjuk, improve knowledge, attitude and skills of cadres companion gerdaristi training course, analyzes the development of nutritional status and the status of development gerdaristi risk pregnant women, analyzes the development of the health status of pregnant women and to support the national program gerdaristi Loving mother Movement (GSI) and 1,000 First Day of Life".

\section{The target population program}

High-risk pregnant women Data obtained from examinations to pregnant women according to standard Integrated ANC both categories of risk factors both medical and non-medical, which is then processed by software assistance with parameter score card Poedji Rochjati be targeted mentoring high-risk pregnant mothers.

\section{Activity program}

Program Gerdaristi implemented in 20 districts across the region Nganjuk, based on data from pregnant women a high risk that had been collected by the midwife coordinator, then a team consisting of Kader, Midwives, and Tim Gerdaristi District to provide assistance in the form of health counseling, health checks as well as the provision of assistance another good form of additional nutrients e.g. milk, which milk is the liquid form of food required to meet the nutritional needs of pregnant women in the supplement nutriational needs that are not found in everyday foods and provision of transport costs for enhance the activity of inspection to the health center. 
Forms of other activities that are not less important is the visit PKK in the utilization of vacant land and the provision of information about the home health and environmental sanitation, it is intended to improve the health status of pregnant women and increase family income.

\section{The Successful of Indicators Program} Indicators that Gerdaristi program at its core is a decrease in MMR and IMR in the district Nganjuk, besides other indicators that show the program's success is the willingness Gerdaristi Pregnant women to be accompanied by up to childbirth that can be ascertained the safety of both the mother or her baby.

\section{Suitability and implementation plan} Gerdaristi program implementation in the district. Nganjuk is in conformity with the original purpose of the program, in addition to the development and implementation of programs in the community can be seen that the socio-economic condition of the family was also influential in the MMR and IMR in Nganjuk, East Java.

\section{Perceptions each informant}

\section{Knowledge}

Gerdaristi program implementation in the district. Nganjuk is in conformity with the original purpose of the program, in addition to the development and implementation of programs in the community can be seen that the socio-economic condition of the family was also influential in the MMR and IMR in Nganjuk, East Java.

\section{Attitude}

The local government Nganjuk addressing Gerdaristi program as a program that should be implemented within minimize or eliminate the MMR and IMR in the district. Nganjuk so that the program is integrated by a budget that has been provided, while for pregnant women at high risk which is the target of the program Gerdaristi welcomed and can receive the program with proven activity of pregnant mothers undergo regular inspections to suppress/ negate MMR and IMR in Nganjuk.

\section{Behavior}

The behavior of pregnant women who were willing and active in conducting health checks on a regular basis at the health center, good coordination between Kader executors (Midwives region and Coordinating midwife) and a good control and infrastructure facilities provided by the Government Nganjuk district is one of the factors that encourage Gerdaristi success of the program.

\section{Involvement}

The involvement of all parties, local governments, program implementers, cadre, community leaders, as well as the role of the family, as well as pregnant women itself indispensable in supporting the success of Gerdaristi program in the Nganjuk district in reducing or eliminating MMR and IMR.

\section{Motivation}

That it is the motivation of the various parties in running the program Gerdaristi is equality objectives in reducing/ preventing MMR and IMR in Nganjuk district. Giving money for transport in assisting cadres of analysis mileage cadres house with clinics were not comparable, especially coupled with visits every week at the patient's home. Thus one form of motivation gerdaristi program's success is awareness of cadres in reducing MMR and IMR.

Differences Gerdaristi Program in each district are both input and processes in the implementation of the program Gerdaristi no difference in their respective districts, the different results caused by several things, including the factor of maternal deaths that cannot be predicted from the beginning e.g. amniotic fluid embolism. The results of the program Gerdaristi been judged already to reduce mortality of mother and baby in the 
Journal of Maternal and Child Health (2016), 1(4): 268-276

https://doi.org/10.26911/thejmch.2016.01.04.08

Nganjuk, but with a reduction in mortality that can not be considered as a measure of success of the program, even though all parties have done the maximum effort in accordance with its function in the running program Geradristi but more important is the level of awareness of high-risk pregnant women in conducting health checks during pregnancy so as to support the implementation of the program Gerdaristi.

Officers Skill who run the program Gerdaristi

Skills program officer Gerdaristi is needed in the success of the program, Kader companion, midwife Gerdaristi, as well as health workers in health centers is the officer leading direct contact with program targets, namely pregnant women at high risk, in other words the skills of officers conduct a major factor supporting the success of the program Gerdaristi, the participation of pregnant women and cadres. From the data on attendance of pregnant women who reached $100 \%$ at the health center during the examination shows that the participation of mothers towards this activity is very high, but the participation and support of the family has not looked though the main purpose of this activity is one of them enhance the participation of the family.

Cadre participation in supporting Gerdaristi program is needed, from the results obtained that the role of cadres in this program is not maximized because of the testimony of several pregnant women do not understand their purpose for coming to Gerdaristi Program. Participation is less than the maximum possible slah of which is due to transportation budget given to cadres inadequate.

\section{Factors inhibiting and supporting program}

Whereas in the implementation of programs in the community Gerdaristi there are some few factors that constrain and a supporting factor. Factors-factors that become an obstacle in the implementation of Gerdaristi program can be used as an input for policy makers in evaluating the program, so it can be used as a basis to determine further policy towards the implementation of the next program. While the factors that support can be used as a means of hyper Gerdaristi program in order to better and achieve success in reducing MMR and IMR in Nganjuk.

Implementation of the program Gerdaristi in Nganjuk has been implemented in accordance with the establishment plan. The results obtained have been able to reduce the number of maternal and infant mortality in Nganjuk. Although there are some things that have not been up implementation of which are still finding some cadres who do not provide guidance at home.

\section{REFERENCE}

Afrasiabi, N (2014). The Feffect of High Risk Pregnancy on Neonatal Duration of Stay in the Neonatal Intensive Care Unit. Iranian Journal of Pediatrics. 24 (4): 423-428

Bapenas (2010). Report on the Achievement of the MDGs in Indonesia. Jakarta: Ministry of National Development Planning.

A Bari, Mazhar SB (2012). Maternal and perinatal outcomes of high risk versus low risk pregnancies in tertiary care settings. Pakistan: Rawal Medical Journal. 37 (3): 304-308.

Berg, Marie A (2005). Midwifery of childbearing Care for Women at High Risk: Genuine Caring in Caring for the Genuine. The Journal of Perinatal Education. Genuine. 14 (1): 9-21

BPKB, East Java (2007). Assistance Module. Surabaya: www.damandiri. or.id. 
Brooten, Dorothy. APN-Physician Collaboration in Caring for Women With High-risk pregnancies. Journal of Nursing Scholarship. 37 (2): 178-184

Budi IS (2012). Reducing the negative impact of the high risk of pregnant women through training of village midwifes. Journal of Public Health. 3 (1): 1-7.

Cresswell J (2010). Research Design. Yogyakarta: Student Library.

NK Denzin and YS Lincoln (2011). The SAGE Handbook of qualitative Research. California: Sara and George (SAGE) Publication.

$\mathrm{MOH}$. Antenatal Care guidelines in 2004. Basic Service Level. Jakarta: MOH. (2001). Indonesia Health Profile.

Meghna Desai (2013). An Analysis of pregancy-Related Mortality in the KEMRI/ CDC Health and Demographic Surveillance System in Western Kenya. PLoS One J. 8: 1-11.

Nganjuk District Health Office (2013). Health Profile Nganjuk. Nganjuk District Health Office.

Febriana A, Setyawan H, and Palato B (2007). Risk Factors that influence Maternal Mortality. Journal of Public Health. 7: 174-187.

Hernandez JC and Moser CM (2013). Community Level Risk Factors for Maternal in Madagascar. African Journal of Reproductive Health. 17 (4): 118-129.

Kothari CL (2010). Assessing Maternal risk for fetal-infant mortality: Populationbased Study to prioritize risk reduction in a start community health. Matern Child Health J. 15: 68-76

Mahmudah U (2011). Maternal and Neonatal Factors Associated with Perinatal Death Kejasian. Journal of Public Health. 7(1): 41-50
Manuaba (2012). Obstetrics, Gynecology and Family Planning for Education Midwives. Jakarta: EGC. (2005). Risk Approach Strategy. Jakarta: EGC.

Martaadisoebrata D, Sastrawinata R, and Saifuddin A (2005). Anthology of Social Obstetrics and Gynecology. Jakarta: PT. Yayasan Bina Library Sarwono Prawirohardjo.

Mochtar R (2000). Synopsis of Obstetrics. Jakarta: EGC.

Moleong LJ (2014). Qualitative Research Methods Revised edition. Bandung: Teen Rosda paper.

Murti B (2013). Design and Sample Size For Quantitative and Qualitative Research in the Field of Health. Yogyakarta: Gadjah Mada University Press.

Nursalam (2013). Methodology of Nursing Research: A Practical Approach Edition 3. The Jakarta. Salemba Medika

Paramita and Kristiana L (2013). A Focus Group Discussion Techniques in Qualitative Research. Health Systems Research Bulletin. 16(2): 117-127.

Pell C (2013). Factors Affecting Attendance Antenatal Care: Results from Quality Studies Studies in Ghana, Kenya and Malawi. PLoS One J. 8: 1-11.

Pratomo J (2003). Maternal Mortality and Mortality Pernatal on Case Referral in Hospital Dr. Kariadi. Thesis Program Specialist Education Obstetrics and Gynaecology FK UNDIP. Semarang.

Robert Greene AR and GJ (2009). Book Smart Social Worker. Jakarta: Mountain Majesty.

Rochjati P (2003). In Pregnancy Antenatal Screening. Surabaya: FK. UNAIR.

Ronsmans C and Graham WJ (2006). Maternal mortality: who, when, where, and why. The Lancet Maternal 
Journal of Maternal and Child Health (2016), 1(4): 268-276

https://doi.org/10.26911/thejmch.2016.01.04.08

Survival Series steering group. 368: 1189-1200

Saifuddin AB. National Reference Books (2000). Maternal and Neonatal Health Services. Jakarta: Yayasan Bina Library Sarwono Prawirohardjo.

Sarwono (2008). Obstetrics. Jakarta: PT Bina Library Sarwono Prawirohardjo.

IDHS (2012). The Indonesian Demographic and Health Survey. Jakarta: The Central Bureau of Statistics.

Senewe FP and Sulityowati N (2004). The Factors related to the complication of delivery in the last three years in Indonesia. Health Research Bulletin. 32(2): 83-91

Sugiarti (2012). Efforts to empower pregnant women for early detection of high-risk pregnancy trimester one.
The Indonesian Journal of Public Health. 9(1): 27-36

Sutopo (2002). Qualitative Research Methods. Surakarta: UNS.

Wiknjosastro H (2008). Obstetrics. Jakarta: PT. Yayasan Bina Library Sarwono Prawirohardjo.

Yego F (2014). Risk factors for maternal mortality in a Tertiary Hospital in Kenya. BMC Pregnancy and Childbirth. 14(38): 2-9

Yin RK (2008). Case Study Design and Methods. Jakarta: King Grafindo Persada.

Yulifah R (2009). Community of Midwifery Care. Jakarta: Salemba Medika. 